\title{
Philipp Ther, Ciemna strona państw narodowych. Czystki etniczne w nowoczesnej Europie, Wydawnictwo Poznańskie, Poznań 2012, ss. 488
}

$\mathrm{P}$ hilipp Ther od 2010 roku jest pracownikiem Eastern European Institute na Uniwersytecie Wiedeńskim. W przeszłości wykładał m.in. na Center For European Studies w Harvardzie, Europa - Universität Viadrina we Frankfurcie nad Odrą oraz na European University Institute we Florencji. Jest autorem prac naukowych poświęconych historii nacjonalizmu oraz migracjom, $\mathrm{w}$ tym przesiedleniom ludności polskiej ze Wschodu po II wojnie światowej, które opisał w pracy Deutsche und polnische Vertriebene: Gesellschaft und Vertriebenenpolitik in der SBZI DDR und in Polen 1945-1956.

Ciemna strona państw narodowych. Czystki etniczne w nowoczesnej Europie wydana została w przekładzie Tomasza Gabisia przy współpracy z Centrum Studiów Niemieckich i Europejskich im. Willy'ego Brandta Uniwersytetu Wrocławskiego. Składa się z pięciu rozdziałów, a także autorskiego podziękowania oraz przedmowy do wydania polskiego pióra Włodzimierza Borodzieja, pracownika naukowego Uniwersytetu Warszawskiego.

Rozdział pierwszy jest wprowadzeniem, w którym Autor przybliża tematykę swojej pracy, omawia dotychczasowy stan badań oraz uzasadnia problemowo - chronologiczny układ publikacji. Druga część poświęcona jest natomiast uwarunkowaniom czystek etnicznych. Zdaniem Thera, ich zastosowanie na szeroką skalę możliwe było dzięki ideologii nowoczesnego nacjonalizmu, która doprowadziła do powstania państw narodowych, w wyniku czego pojawił się w nich problem z mniejszościami. Kolejnymi, równie ważnymi przyczynami są zdaniem niemieckiego badacza: postęp technologiczny oraz nietolerancja, której korzeniem jest chrześcijańska wrogość do innowierców z czasem zmieniła w niechęć wobec innych grup etnicznych.

Trzeci, najważniejszy i najobszerniejszy rozdział pracy, poświęcony jest czystkom etnicznym w XX wieku. Autor rozmieścił go chronologicznie w czterech podrozdziałach. W pierwszym, poświęconym wydarzeniom z lat 1912-1925, przyblżea początki czystek etnicznych, które po raz pierwszy miały miejsce w czasie wojen bałkańskich z lat 1912-1913. Opisuje w nim także masowe migracje ludności w czasie I wojny światowej i w okresie powojennym oraz postanowienia traktatów pokojowych, które usankcjonowały czystkę etniczną, jako sposób rozwiązywania problemów narodowościowych. Podrozdział drugi opisuje masowe deportacje i przesiedlenia, które zaczęły się w wyniku postanowień układu monachijskiego 
w 1938 roku i trwały w czasie II wojny światowej. Autor szczegółowo opisał holocaust oraz polsko-ukraiński i chorwacko-serbski konflikt etnicznych będących przykładem „wojny w wojnie”. Część trzecia opisuje powojenne czystki etniczne m.in. w Polsce i Czechosłowacji. Były one usankcjonowane porozumieniami mocarstw na konferencjach w Teheranie, Jałcie i Poczdamie,. Omawia również import europejskiego sposobu rozwiązywania problemów na linii naród tytularny-mniejszości narodowe, na przykładzie Indii i Palestyny. Czwarta i ostatnia część tego rozdziału poświęcona jest konfliktom w krajach byłej Jugosławii i na Kaukazie w latach 90. W tym czasie których polityka masowych przesiedleń i deportacji ustąpiła - chociaż miało to miejsce jedynie w przypadku Bośni - realizacji koncepcji powrotu uchodźców do dawnych miejsc zamieszkania.

Czwarty rozdział zawiera uwagi końcowe, natomiast w piątym pojawia się komentowana bibliografia, w której opisane są najważniejsze, zdaniem Autora, pozycje bibliograficzne i źródłowe. Koniec pracy to indeks geograficzny i osobowy.

We wstępie Włodzimierz Borodziej określa publikację Philippa Thera jako „rewizjonistyczną” i prezentującą nowe spojrzenie na znane historykom problemy ${ }^{1}$. Trudno się z taką tezą nie zgodzić. Autor wymienia kilka najważniejszych powodów wykorzystania czystek etnicznych jako sposobu rozwiązania problemów narodowościowych. Zalicza do nich: nowoczesny nacjonalizm i związane z nim terytorialne myślenie, prowadzące do konfliktów w regionach działania kilka ruchów narodowych; ideał homogeniczności i program narodowego ujednolicenia całej ludności państwa, co - wobec mniejszości narodowych - miało często odwrotne skutki i powodowało opór wobec narodu tytularnego; współdziałanie radykalnego nacjonalizmu i mechanizmów nowoczesnego państwa narodowego; dążenie do ścisłego i naukowego opisu populacji za pomocą statystyki zmuszającego do ustalenia narodowości oraz późniejsze nadużywanie tych danych w celu zmiany - poprzez osadnictwo - etnografii poszczególnych obszarów zgodnie z interesem narodu tytularnego, co ostatecznie doprowadziło - wobec fiaska tej koncepcji - do powstania idei czystek etnicznych oraz jej realizacji ${ }^{2}$.

Autor krytykuje naukowe podejście do czystek etnicznych i związane z nim techniczne słownictwo, które nie oddaje skali cierpienia milionów ludzi, lecz ukazuje je jako proces, w którym jedynym problemem jest fizyczna wykonalność. Ther stawia również odważne tezy. Analizując przyczyny czystek etnicznych dochodzi do wniosku, że nie stały za nimi emocje, takie jak nienawiść, czy chęć zemsty, lecz poli-

1 W. Borodziej, Przedmowa do wydania polskiego, [w:] P. Ther, Ciemna strona państw narodowych. Czystki etniczne w nowoczesnej Europie, Poznań 2012, s. 13.

2 P. Ther, Ciemna strona państw narodowych. Czystki etniczne w nowoczesnej Europie, Poznań 2012, s. 105-109. 
tyczne strategie. Podkreśla, że Wielka Brytania i Francja już przy układzie w Neuilly po I wojnie światowej uznały je za skuteczny sposób likwidowania konfliktów między państwami, a stan taki trwał do mniej więcej 1946 roku. Większa zmiana nastąpiła, zdaniem autora, dopiero w czasie wojny domowej w Bośni, kiedy za „dobre” rozwiązanie uznano nie kolejne wysiedlenia, lecz powrót uchodźców do poprzednich miejsc zamieszkania. Niemiecki badacz podkreśla również istotną rolę konfliktu w byłej Jugosławii, gdyż w jego wyniku czystkę etniczną uznano - w myśl prawa międzynarodowego - za czyn karalny ${ }^{3}$. Autor stwierdza również, że homogeniczne państwo narodowe, którego powstanie przyczyniło się do zastosowania czystek etnicznych, jest „europejskim wynalazkiem”, zaimportowanym później w innych częściach świata, które w książce pokazane są na przykładach Palestyny i Indii.

Zdaniem niemieckiego badacza, od momentu powstania nowoczesnych państw narodowych mniejszości stały się podmiotem prawa międzynarodowego, wciąż jednak postrzegano je jako problem i zagrożenie ${ }^{5}$. Ther stawia w tym momencie ważne pytania: czy problemem nie były w tym przypadku centralistyczne państwa narodowe, a nie mniejszości? Czy istotą problemu nie był fakt, że roszczenia do władzy na określonym terytorium, na którym działały przeciwstawne ruchy narodowe, nie były możliwe do pogodzenia i wykluczały jakikolwiek kompromis? Autor niewątpliwie prowokuje do dyskusji, a w zakończeniu idzie jeszcze dalej wysuwając przypuszczenie, że następną sposobem rozwiązywania problemów narodowościowych - po czystkach etnicznych - nie będzie wcale rozwiązanie bośniackie, lecz ludobójstwo ${ }^{6}$.

Ciemna strone państw narodowych... mimo dużej objętości czyta się bardzo szybko. Philipp Ther dysponuje lekkim piórem, nie atakuje też czytelnika nadmiarem naukowych pojęć. Wyraźna empatia dla strony pokrzywdzonej, którą zawsze była ludność cywilna, nie sprawia, że Autor ucieka od zauważenia faktu, że ofiara mogła być również sprawcą przemocy lub jej przyczyną. Publikacja wyróżnia się obiektywizmem i odwagą w stawianiu kontrowersyjnych tez i pytań. Oprawa graficzna książki jest skromna i ograniczona jedynie do okładki, która - utrzymana w czarno-białej kolorystyce - nawiązuje do treści publikacji.

Praca nie jest jednak pozbawiona wad. Bibliografia i przypisy są dość ograniczone, co niemiecki historyk wytłumaczył dużą ilością wykorzystanej literatury, której pełny spis zajął by „kilka tomów”. W takiej sytuacji brakuje możliwości pełnej weryfikacji wielu faktów oraz danych liczbowych. Poza tym, w kilku przypad-

\footnotetext{
${ }^{3}$ Ibidem, s. 18.

${ }^{4}$ Ibidem, s. 26.

${ }^{5}$ Ibidem, s. 21.

${ }^{6}$ Ibidem, s. 445.

7 Ibidem, s. 446
} 
kach trudno zgodzić się z Therem, jak chociażby ze stwierdzeniem, że w 1947 roku w Polsce miał miejsce plebiscyt (chodziło tutaj zapewne o referendum z roku 1946), czy też z określeniem „nacjonalistyczna dyktatura” dotyczącym sytuacji na Śląsku w 1945 roku$^{8}$.

Reasumując, najnowszą publikację Philippa Thera warto polecić wszystkim zainteresowanym tematyką czystek etnicznych i masowych przesiedleń ludności w XX wieku, nie tylko historykom. Kontrowersyjne tezy Autora mogą być powodem dyskusji nad tym zagadnieniem i taki też był zapewne cel tej publikacji. Nieliczne pomyłki merytoryczne i faktograficzne ${ }^{9}$ nie mogą obniżyć bardzo pozytywnej oceny niniejszej pozycji.

Bartosz Borys (Wrocław)

8 „W okolicach zamieszkałych przez autochtonów już w 1945 roku powstała nacjonalistyczna dyktatura - polscy osiedleńcy szpiegowali ich nawet w sferze prywatnej [...]" [w:] ibidem, s. 310 .

9 Aleksander Zawadzki był wojewodą śląskim, a nie „górnośląskim” jak pisze Ther. Ibidem, s. 289. Por. P. Madajczyk, Przyłączenie Śląsa Opolskiego do Polski 1945-1948, Warszawa 1996, s. 110; M. Fic, Województwo ślasko-dąbrowskie czy województwo ślaskie, [w:] Województwo ślaskie 1945-1950, red. A. Dziurok, Katowice 2007, s. 89-90. 